\title{
TEACHING ENGLISH TO THE TEACHERS OF SPECIAL NEEDS STUDENTS AT PANTI SOSIAL BINA GRAHITA BELAIAN KASIH
}

\author{
Murniati $^{1)}$ dan Junita ${ }^{2)}$ \\ 1), 2) Program Studi Bahasa dan Budaya Inggris, Universitas Bunda Mulia \\ Diterima 26 Maret 2021 / Disetujui 30 Maret 2021
}

\begin{abstract}
All teaches need to improve themselves in terms of content and the teaching methods. Unfortunately, there has been a little enrichment delivered due to the pandemic which still occurs in 2021. This community service, therefore, is delivered to the teachers of special needs students at Panti Sosial Bina Grahita Belaian Kasih since to enrich their English knowledge as well as teaching skills for the special needs students. Needs analysis was administered to find (1) the Present Situation Analysis of the teachers, (2) the Learning Situation Analysis which cover the delivery of the community services, and (3) the Target Situation Analysis which cover the topics delivered during the community services. It was found out that there were twelve (12) teachers who would join this enrichment English class. Since bot all of them were English teachers, the English content should also be discussed during the community services. Next, the community services delivered five times through google meet and zoom meeting, on Wednesdays and Fridays in March 2021. The topics delivered are (1) learning styles and teaching methods for special needs students, (2) the English alphabets, (3) shapes and colors, (4) emotions, and (5) action verbs in English. The community services ran well. For better results, more meetings are needed to enrich the teachers' teaching skills as well as their English abilities and knowledge, especially which are related to the special needs students.
\end{abstract}

Keywords: Teachers of special needs students, needs analysis, ESP class

\begin{abstract}
ABSTRAK
Guru perlu meningkatkan diri dalam hal konten dan metode pengajaran yang biasanya diberikan lewat seminar atau workshop. Sayangnya, hanya sedikit seminar pengayaan yang disampaikan akibat pandemi yang masih terjadi di tahun 2021. Oleh karena itu pengabdian masyarakat ini disampaikan kepada para guru tyang mengajar anak kebutuhan khusus di Panti Sosial Bina Grahita Belaian Kasih. Analisis kebutuhan dilakukan untuk mengetahui (1) Analisis Situasi Saat Ini dari para guru, (2) Analisis Situasi Pembelajaran yang meliputi penyampaian layanan masyarakat, dan (3) Analisis Situasi Sasaran yang mencakup topik-topik yang disampaikan selama pengabdian kepada masyarakat. . Diketahui bahwa ada dua belas (12) guru yang akan mengambil kelas pengayaan bahasa Inggris ini. Karena tidak semuanya adalah guru bahasa Inggris, konten bahasa Inggris juga harus dibahas selama pengabdian masyarakat. Selanjutnya pengabdian masyarakat disampaikan sebanyak lima kali melalui pertemuan google meet and zoom, pada hari Rabu dan Jumat pada bulan Maret 2021. Topik yang disampaikan adalah (1) gaya belajar dan metode pengajaran untuk anak berkebutuhan khusus, (2) alfabet inggris, (3) bentuk dan warna, (4) emosi, dan (5) kata kerja tindakan dalam bahasa Inggris. Kegiatan ini telah berjalan dengan baik, namun untuk hasil yang lebih baik, lebih banyak pertemuan diperlukan untuk memperkaya keterampilan mengajar para guru serta keterampilan dan pengetahuan bahasa Inggris mereka, terutama yang yang berhubungan dengan anak berkebutuhan khusus.
\end{abstract}

Kata Kunci: Guru Panti Tuna Grahita, analisis kebutuhan, Kelas ESP.

*Korespondensi Penulis:
E-mail: murniati@bundamulia.ac.id 


\section{INTRODUCTION}

Since the first confirmed cases in March 2020, the novel corona virus (COVID-19) pandemic has overwhelmed several aspects of life in the world. Corona virus does affect not only the business or education sectors but also the social sector, such as homes for the disabled, especially in the Jakarta area. The situation has now hindered volunteers who usually come regularly to help with several activities usually carried out every day. This impact has also been felt by one of the home for disabled in West Jakarta, namely the Panti Tuna Grahita Belaian Kasih, located in Pegadungan, Kalideres. Panti Tuna Grahita is a home for the disabled that contains mentally disabled children, commonly called mental retardation. They usually have an IQ (Intelligence Quotient) below normal children's average, causing impaired intellectual and intellectual function. Moreover, some of them are also accompanied by physical limitations or physical disabilities.

There are many activities in this home for disabled, one of which is learning and teaching activities carried out for some children selected before entering Special Schools. Apart from teaching speaking and listening, the students are also provided with simple English vocabulary by volunteers each week. However, unfortunately, the students' English teaching and learning activities have to be temporarily stopped due to unfavourable circumstances. The teaching and learning activities by volunteers were limited due to the pandemic, and the teachers there do not have English background and the knowledge to teach English for children with special needs.

Because of the conditions which have already been mentioned above, ten (10) lecturers of Prodi Bahasa dan Budaya Inggris - Universitas Bunda Mulia, tried to find out the teachers needs in order teaching English in emergency teaching there through the needs analysis. According to
North et al. (2018), "Needs analysis is the process of gathering information before or during a course to determine objective that can be analyzed in order to create an inventory of aims and suitable activities for that course." Moreover, Basturkmen (2010) stated that needs analysis identifies the learners' specific language and skills. In simple words, needs analysis is a procedure to collect information about learners' needs (Richards, 2001). Needs analysis and English for specific purposes (ESP) are closely related because they are one unit. It is impossible to conduct English for specific purposes without conducting a needs analysis. According to Paltridge and Starfield (2013), English for specific purposes refers to the teaching and learning English as a second or foreign language where the learners' goal is to use English in a particular domain. As for a more significant definition of ESP, Hutchinson and Waters (1987) theorize that ESP is an approach to language teaching. All conclusions as to content and method are based on the learner's reason for learning. In this case, the teachers at Panti Tuna Grahita Belaian Kasih need English knowledge to be delivered to the students in the emergency right now for the pandemic has not ended yet.

In an emergency, ESP can be one of the answers to solve this problem. Basturkmen (2010) stated that teaching the learners according to their needs can be more effective than teaching general English. It can be claimed that because ESP courses provide students' interests and needs, they are more likely to produce high levels of motivation. It can be assumed that students will be more concerned with topics and texts related to their work or study areas. If students are more interested, then learning is more likely to occur. It can also be argued that ESP courses are more efficient because they have more limited aims than general English courses. Like the writers have mentioned above, ESP courses are based on needs analysis, the learning objectives are more highly proscribed than 
would be the case in general English courses. Thus, it is not surprising that learning outcomes may be perceived more favourably. Limited and highly specified aims are more likely to be achievable (Basturkmen, 2010). Therefore, this paper was conducted to determine the teachers' target and learning needs at the Panti Tuna Grahita Belaian Kasih. The needs analysis was used to design the syllabus for the teachers at Panti Tuna Grahita Belaian Kasih. The syllabus which had already made was used as the guideline for the teaching process by Bahasa dan Budaya Inggris lecturers for almost one month.

\section{STATEMENT OF THE PROBLEM}

Before the pandemic occurred, there were many activities at Panti Tuna Grahita Belaian Kasih. One of them is learning and teaching English activities carried out by volunteers every week. Nevertheless, unfortunately, this activity must be stopped because the corona virus is increasingly spreading. In addition, the teachers who are responsible for the learning activities there have no background in English and do not have sufficient English skills to teach English to the students. In other words, the English learning and teaching process only rely on the volunteers. Therefore, these problems encourage the lecturers of Bahasa dan Budaya Inggris, Universitas Bunda Mulia, to do the community service to the teachers at the Panti Tuna Grahita Belaian Kasih in order to find out what their target and learning needs and how are the syllabus design.

\section{THE OBJECTIVES AND SIGNIFICANCES}

This community service's objectives were to support the teachers at Panti Tuna Grahita Belaian Kasih with the English knowledge and English teaching skills based on their needs so that the learning and teaching English activities will continue during the pandemic.

\section{METHODOLOGY}

The implementation of this community service combined several steps. First, needs analysis was administered to gathered the data before conducting the needs analysis. The data of this community service was gathered from the interview and focus group discussion. The target populations of the need analysis were the participants themselves. Next, observation was conducted during the teaching learning processes.

During the needs analysis, there had been two steps applied. The first step was interviewing the Head of Implementation Unit for Social Coaching Institution "Belaian Kasih" about the condition of the children and the teachers and whether English was introduced and needed by the students.

Next, to answer the teachers' target and learning needs at Panti Tuna Grahita Belaian Kasih, a focus group discussion was conducted on February $17^{\text {th }} 2021$ ZOOM Meeting with 12 teachers at Panti Sosial Tuna Grahita Belaian Kasih. Several questions were discussed that day related to the teachers' present situation, learning needs, and target needs. Some of the questions were:

1. How many teachers do teach the children?

2. Do all the teachers need the English language?

3. What are the English skills that need to be taught to the teachers?

4. What are the English topics that need to be taught for the teachers?

5. What is the method used in the teaching and learning process there?

6. How many children that they need to teach? 
7. What are the problems during the teaching process?

8. What is the preferred application to be used in the teaching and learning process?

9. When is the available time to learn?

10. How long will the class be?

11. What is the device used by the learners?

12. When will the class start?

After administering the focus group discussion, the next step was preparing the planned topics that had to be delivered in the teaching and learning process.

\section{RESULTS AND DISCCUSIONS}

\section{Needs Analysis}

According to Hutchinson and Waters (1987), ESP is an approach to language learning based on learners' needs. In other words, ESP is the way to teach students who needs specific skill and it helps the students master English based on what they need. Besides, Tomlinson and Masuhara (2004) acknowledge that ESP uses needs analysis as a tool to fulfill the learner's specific needs. Meaning needs analysis is one thing that must be done before the teaching and learning process be held.

There are several definitions from some experts about needs analysis. Basturkmen (2010, p.17) says that needs analysis identifies skills and language used to determine a course's content. Meaning that need analysis is the main thing that people should do before going to the teaching and learning process. Meanwhile, Graves (2000, p.98) states that need analysis is a systematic and ongoing process to gather information about students' needs, interpret the information, and then decide to determine their needs.
The focus of needs analysis is on what the students need and how we interpret them. The decision-maker must find out and summarize what the students need to make

This community service which was delivered in the form of teaching learning process are based on the results of needs analysis (Woodrow, 2017).

\section{The Results of Needs Analysis}

The needs analysis conducted covers the main areas. The first area was the Present Situation Analysis (PSA). The PSA was related to both the participants and the teachers themselves. Next, the Learning Situation Analysis were also investigated. They covered how the courses should have been delivered. Finally, the Target Situation Analysis were also looked into carefully to find the goals of the courses.

Regarding the Present Situation analysis (PSA), there were fourteen (14) participants who would join the English course. One of them is the head of the teachers. While the other thirteen are the volunteers teaching the disability students during pandemic. All of them are studying in the same course. The range of the English proficiency levels of the participants are from basic to intermediate levels, therefore, they argued that they need the English course to enrich their English ability as well as their ability to teach the English language to the students with the special needs.

The second data gathered from the needs analysis is the learning Situation Analysis. It basically discussed how the community service was conducted with certain participants. It was found out that the teachers were available on Wednesdays and Fridays After lunch, for about 90 minutes. The participants argued that they need the course as soon as possible. It was decided that the courses 
should start in the following week on Fridays, Due to the pandemic, it must have been conducted online through either google meet or zoom meeting; the two apps which were familiar for both the instructors and the participants. During the focus group discussions, it was also found out that almost half of the participants shared their devices. The reason was mainly because they were gathered in the same room during the focus group discussions. Regarding the discussion, the room was a bit noisy. There would be a possibility that when one participant un-mute the microphone to participate, the voice had become unclear due to the noise disturbance. It was also found out that the participants would also gather at the same place during the English course delivered as the community services. The participants were all using their smartphones at that time. Regarding the length of the courses, Woodrow (2017) has argued that an English for Specific Purposes class can be short; it depends on the needs of the participants themselves. It is, therefore, decided that the course should be delivered 5 times, twice a week.

Regarding the Target Situations Analysis, it was found out that the topics which were taught to the students were mainly about vocabularies. The vocabularies taught were the English alphabets, colors, shapes, emotions and action verbs. The verbs taught were all in the present forms. Next, regarding the skills practiced during the course, the participants said that they needed two skills: speaking and listening skills. They argued that their students would not need reading and writing skills. In relation to the delivery of the lesson in the class, the teachers argued that they often faced some problems related to the range of the age of the students. Unlike other schools, the students at this Panti had different ages, from young learners, teenagers, and perhaps adults were all gathered in a classroom studying the same topics. In this case, the teaching methods and leaning styles might also be delivered to the participants during the community services.

\section{The Delivery of the Community Services}

There were five meetings delivered in this community services. Ten (10) lectures from Prodi Bahasa dan Budaya Inggris Universitas Bunda Mulia were participated as the speakers in those ten meeting. There were two lecturers who were responsible for the delivery of each meeting.

The first meeting was delivered on Friday, $3^{\text {rd }}$ March 2021 by google meet at 13.30 - 15.00. There were two topics delivered in the first meeting. One was learning styles and the other was regarding the teaching method which was suitable for the special needs students. The three types of learning styles: Visual, Audio and kinesthetic learners were discussed, together with the teaching techniques on how to teach them (Vincent \& Ross, 2001). Next, a teaching method named Total Physical Response (TPR) was explained. TPR was chosen since it focuses on the coordination between speech and coordination. The teacher was expected to say commands the English language taught. The students respond with the whole-body action. The movement was expected to enhance the students' understanding in English (Richards \& Rodgers, 2014).

The second meeting was held on Wednesday, $5^{\text {th }}$ March 2021 from 13.30 15.00. The topic was shifted to teaching Vocabularies for special needs students. The vocabularies were limited to teaching the English alphabets. English songs, such as ABC Songs, Phonics Songs, Lowercase, and Super Simple ABCs, could be used to introduce the English alphabets to the students. Following the Total Physical 
Response method, the songs should first be played. The teachers could show the alphabet mentioned in the songs. After that, the students could also sing the songs together. If the students could not sing the songs, they were allowed to touch the alphabets prepared by the teachers on a piece of paper. In addition, teaching aids such as flash cards could also be used and beneficial to teach alphabets which were similar, such as $\mathrm{G}$ and $\mathrm{J}$, and vowels such as A, I, U, E, and O.

The third meeting was on $10^{\text {th }}$ March 2021, from 13.30 to 15.00. The topics was shapes and colors. Unlike teaching alphabets, the activity began with a little review of the names of shapes in English such as square, rectangle, triangle, circle, etc. Then, the discussion continued with the teaching method, in which the speaker explains the engage activities that can be conducted, such as showing some pictures or items which had similar shapes. The students were asked to guess the name of the shapes. After that, the teacher could start teaching the names of shapes in English to their students. There were two ways suggested to explain these names. The first was showing flash cards or realia to students and explaining the names of the shapes and their pronunciation in English. The second way was to use songs, because the presenters received input from the previous session that the students at the Social Institution liked to learn by using songs. After completing the explanation, the next activity which could be delivered in the practice stage was playing games related to the names of shapes in English. As for the first game, the teacher could paste various shapes around the room or a blackboard. Then the teacher says the name of the shape in English and the student had to run to the shape. For the second game, students were asked to draw a shape on the blackboard after being mentioned by the teacher. Then for the last game, students were given a picture of a robot head that had various shapes. When the teacher mentioned one of the shapes, the student had to be able to show that shape in the picture.

The second topic delivered in the third meeting was learning colors in English. The activity began with a review of colors that were rarely known, such as lime, turquoise, and navy. Next, some activities which could be used in class was discussed. The first was about the explanation of the color relationship. In this activity, the teacher showed one of the colors printed on a piece of paper and said the color. The students who wore clothes of that color had to stand up or point to their clothes. Next, the students could also learn colors from songs.

The fourth meeting was delivered on Friday, $12^{\text {th }}$ March 2021 at $13.30-$ 15.00. The first topic was about the techniques that can be used to teach emotional words to students with special needs. The emotional vocabularies that were targeted were happy, sad, angry, confused, surprised, scared, tired, embarrassed, and bored. The first technique was to use facial expressions. By showing certain expressions and expressing controlled vocabulary, it was expected that students with special needs could associate certain expressions of English words with these words. The next technique was to use context or situation scenarios (for example: accepting gifts from friends, being teased by others, etc.). By using context, the students with special needs could understand the concept of English emotional vocabulary. In addition, sign language for English emotion vocabulary using American Sign Language was also discussed so that the teacher could apply it to teach them to the deaf students.

During the fourth meeting, it was also discussed some activities which could be applied teach English emotional 
vocabulary to the students with special needs. The first activity was to use pieces of cardboard or paperboard with an expressionless face and pieces or paper with a picture of the eyes and mouth with various expressions. The students later were expected to match the eyes and mouth images which match the face to create an expression from the emotion word. The second activity was to show pictures in a certain context (for example: receiving gifts from friends, being teased by others, etc.) The students could draw their expressions when they experienced the situation.

The fifth meeting was held on Wednesday, $17^{\text {th }}$ March 2021 at $13.30-$ 15.00. The topic was about the techniques which could be used in teaching action verbs (verbs) to the students with special needs. The suggested technique was adapted from Total Physical Response. More action verbs were discussed and practiced. The next technique discussed was using pictures to teach action verbs. By using pictures, there were expected that more verbs could be introduced by the teachers. The third technique was using cards. The teachers could make two sets of decks of cards. One set contained cards with pictures, while another set contained the verbs. Later the teacher could show the picture on the card, then asked the students to look for the verb that was on the other pile of cards. Then the last technique was to use matching games. While applying this technique, the teachers could show some pictures and verbs which were on a sheet of paper. Then, the teachers asked the students to match the picture to the verb by making a line between the picture and the verb.

\section{CONCLUSIONS}

In conclusion, it can be said that teachers of special needs students, like other teachers, still need to improve themselves in terms of their English abilities. Teaching methods delivered must also be adjusted to match the special needs students. The teaching methods which might be useful are the methods which apply engage, study and activate lesson stages.

\section{REFERENCES}

Basturkmen, H. (2010). Developing courses in English for specific purposes. London: Palgrave Macmillan.

Graves, K. (2000). Designing language courses: a guide for teachers.

Canada: Heinle \& Heinle Publishers.

Hutchison, T., \& Waters, A. (1987). English for Specific Purposes: a learner-centered approach. England: Cambridge University Press

North, B., Angelova, M., Jarosz, E., \& Rossner, R. (2018). Language course planning. Oxford University Press.

Paltridge, B., \& Starfield, S (Eds.). (2013). The handbook of English for specific purposes. West Sussex: Wiley-Blackwell.

Richards, J. (2001). Curriculum development in language teaching. Cambridge: Cambridge University Press.

Richards, J. C., \& Rodgers, T. S. (2014). Approaches and methods in language teaching. Cambridge university press

Tomlinson, B. \& Masuhara, H. (2004). Developing Language Course Materials. Singapore: RELC.

Vincent, A., \& Ross, D. (2001). Learning Style Awareness. Journal of Research on computing in Education, 33(5).

Woodrow, L. (2017). Introducing course design in English for specific purposes. Routledge. 